\section{Globular Lightning.}

A GREAT deal has been written recently on the various forms of lightning, and the subject itself has so much scientific interest, that it may be worth while to place on record an observation of my own on globular lightning, made years ago, in which the main facts are different from any I have seen described.

On Tuesday, July 23,1878 , I was on board a large yacht at anchor in the harbour of Southampton, England. About two o'clock in the afternoon, when we were about to sail, a violent thunderstorm came up from the west, and as it passed over Southampton, several bolts descended, one of which, as I afterwards learned, struck a church. As the first drops of rain came down on the yacht, I was standing in the after-companionway, looking forward, when my attention was attracted by a bright light apparently near the upper part of the foremast. When I first saw it distinctly, it was about half-mast high, and was falling slowly and directly toward the deck. This light was a ball of fire, a delicate rose-pink in colour, pear-shaped in form, with the large end below, and appeared to be four or five inches in diameter and six or eight inches in length.

When it struck the deck, about forty feet from where I was standing, there was a loud explosion, and it was some minutes before it could be ascertained what damage had resulted. The mate, who stood near the mainmast, about twenty-five feet from where I was, was knocked down, but soon recovered. The same bolt, or part of it, also passed in front of the foremast, down a windsail ventilator, into the galley, where it knocked a large tin pan from the hands of a cook, and upset things generally throughout the culinary department, but injured no one seriously. Of the crew, some were on deck, and others below, but none were really injured, although a few were badly demoralised. A strong ozone-like odour was observed immediately after the explosion, and this remained perceptible for some time.

The officer in charge of the yacht, Captain Matthews, who was forward at the time, and escaped without injury, stated that just after the stroke, he saw "streaks of lightning running around on deck like snakes." I was myself only dazed for a moment by the explosion, and saw distinctly that the deck forward was illuminated with a bright confused light. The owner of the yacht, George Peabody Russell, and his other guests, had gone below when the storm began, and suffered no injury, except possibly from fright, as they were still further away from the stroke.

As soon as the storm had passed, I made careful notes of the whole occurrence, with drawings and measurements, as I was much interested in the subject, and it was the first instance of the kind I had seen at close quarters. An inspection showed that the vessel itself had sustained no material damage, and there were not even permanent marks left on the deck where the ball of fire exploded. A number of other yachts were at anchor quite near our vessel at the time, among them the white Sunbeam, just home from her well-known voyage, but we saw no indications that any of these had been struck. I had no time to inquire, as immediately after the storm we sailed on a cruise to the eastward.

O. C. MARSH.

Yale University, New Haven, Connecticut, December 4.

\section{Large Human Femora in the Church of S. Eustachius, Tavistock.}

TAvistock ABBEY was founded A.1. 96r by Orgar, Earl of Devonshire, and endowed and completed by his son Ordulf A.D. 981. Some bones, said to have been found in an ancient stone coffin in the Abbey ruins, are locally believed to have once formed part of the skeleton of the said Ordulf, a reputed giant. According to William of Malmesbury, this Ordulf could stride across a stream ten feet wide, and he is said, by the same authority, to have torn off the bars from the town gate of Exetcr with his hands, and to have wrenched away the hinges with his feet.

The relics, which are preserved under glass in Tavistock parish church, consist of three thigh bones which originally belonged to three different individuals.

Whilst at Tavistock recently I had an opportunity of measuring these bones : the extreme length of one is $\mathrm{I} f \mathrm{ft} .9 \frac{1}{8}$ in., the second I ft. $8 \frac{3}{8}$ in., and the third I ft. $5^{\frac{1}{4}}$ in. The heights of the original owners were therefore $6 \mathrm{ft}$. 8 . in., $6 \mathrm{ft}$. $5 \frac{1}{2}$ in., and $5 \mathrm{ft} .5^{\frac{1}{4}} \mathrm{in}$. The two larger bones appear to have belonged to strong well-developed men, the other bone is more delicate.

Dunstable. NO. I 364 , VOI. 53]
Worthington G. SMith.

\section{A Lecture Experiment in Surface Tension.}

Wishing to demonstrate to a fairly large audience the wellknown disastrous results of attempting to remove grease stains by placing ether or benzol on them, instead of round them, and then spirally approaching their centres, I hit on the following plan, which gives not only unmistakable but beautiful results.

A circle of paraffin or olive oil is painted on the centre of a filter-paper, which is then dusted over with bone-black. A light blast of air on the paper removes the bone-black from all portions of the paper except the oiled portion, which looms up jet-black on a pale grey ground. The filter-paper is then folded in four wings, so that its edge forms a curved cross, and it is secured in this position by a penholder which has two longitudinal slits cut at right-angles. (This method of folding and securing will be familiar to all who can recall their school-days to the minutiæ of " penholder darts.")

The tip of the oiled apex of the filter-paper is dipped for a moment or two in ether. The paper is then unfolded, dried, and subjected to a second treatment with bone-black, when it will be found that the ether has chased the oil from the apex, and spread it towards the circumference of the paper in a. symmetrical pattern.

It is scarcely necessary to add that there is no virtue in the special method of folding described above, and that a great diversity of beautiful patterns may be obtained by folding the filter-paper, and distributing the oil in other ways.

The Leys School, Cambridge.

DOUGLAS CARNEGie.

\section{An Examination Question in Physics.}

IN the subject of Experimental Physics, B.Sc. Examination for Honours of the University of London (December 5), the fifth question of the second paper stands as follows :-

"A plate of uniaxal crystal, cut with the faces parallel to the axis, is placed between a polariser and an analyser. How would you arrange a source of light and lenses to show a system of rings on a screen?

"Explain how the rings are formed when the polariser and analyser are crossed and the axis is in the plane of polarisation of the incident light." (The italics are my own.)

As the B.Sc. Honours is the highest examination of the University, the questions set therein are naturally regarded by students as important tests of knowledge ; and I think it would, therefore, be of considerable scientific interest if the examiners would kindly state their intention in setting this question, and the nature of the answer they expected to receive.

Queen's College, Harley Street, W. E. F. HERroun.

\section{"Linotænia maritima" (Leach).}

WILL you kindly allow me to put on record a new locality for this marine centipede?-Bexhill, just above high-water mark. The single specimen taken was kindly identified for me by $\mathrm{Mr}$. R. I. Pocock, of the British Museum (Natural History).

9 Cavendish Road, Harringay, N.

\title{
THE TRANSFORMATIONS OF INSECTS
}

SO much special work has been done during the last thirty years upon the transformations of insects, that I lately resolved to spend some time in reviewing the most important facts which have been ascertained respecting the structural changes which take place before or during pupation. I had not gone far before I found it necessary to clear up my own thoughts as to the nature of insect metamorphosis, and the way in which it had come about. Some preliminary considerations upon these points, inferred from facts which have long been known, I now propose to discuss, leaving the more special facts to some future occasion.

Three naturalists, Fritz Müller (1864), ${ }^{1}$ Friedrich Brauer (1869), ${ }^{2}$ and Sir John Lubbock (1874), ${ }^{3}$ have in

1 "Facts for Darwin" (Für Darwin).

2 Verh. Zool. bot. Ges. Wien (1869). Of less importance is Part 2 (1878). 3 "Origin and Metamorphoses of Insects." (Appeared originally in NATURE; I 873 ) 